\title{
HOW TO MAKE A PATENT MARKET
}

\author{
Mark A. Lemley* \\ Nathan Myhrvold**
}

Imagine a stock market in which buyers and sellers couldn't find out the prices at which anyone else sold a share of stock. If you wanted to buy (or sell) a share of stock, you would have to guess what it was worth. The result, everyone would agree, would be massively inefficient. Willing buyers and sellers would often miss each other. The price at which a sale did close would vary widely from sale to sale. And those who had a source of private or inside information would be able to exploit others. Some trades might occur in such a system, but surely not anything like the volume in today's stock markets. Surely no one would intentionally design a system in which trades had to be "blind" in this way.

Patents, however, exist in just such a blind market. Want to know if you are getting a good deal on a patent license or technology acquisition? Too bad. Even if that patent or ones like it have been licensed dozens of times before, the terms of those licenses, including the price itself, will almost invariably be confidential. Patent owners who want to put their rights up for sale face the same problem.

The result? Willing licensors and licensees can't find each other. Patent auctions often fizzle, because without a thick market—one with an array of buyers and sellers bidding on price-no one can know whether they are getting a steal or being had. When parties do license patents, the prices are (to the extent we can tell) all over the map. And the rest of the world has no idea what those prices are. This, in turn, means that courts lack adequate benchmarks to determine a "reasonable royalty" when companies infringe patents. The lack of a real, rational market for patent licenses encourages companies to ignore patent rights

\footnotetext{
* Mark Lemley is the William H. Neukom Professor at Stanford Law School and a patent litigator at Keker \& Van Nest.

** Nathan Myhrvold is CEO of Intellectual Ventures, former CTO of Microsoft, and founder of Microsoft Research.
} 
altogether, because they cannot make any reasonable forecast of what it would cost them to obtain the licenses they need and because they fear that they will pay too much for a technology their competitors ignore or get on the cheap. At the same time, ignorance of prices permits unscrupulous patent owners to "hold up" companies that make products by demanding a high royalty from a jury that has no way of knowing what the patent is actually worth.

The solution is straightforward-require publication of patent assignment and license terms. Doing so will not magically make the market for patents work like a stock exchange; there will still be significant uncertainty about whether a patent is valid and what it covers, particularly since patents tend by their nature to be unique goods. But it will permit the aggregate record of what companies pay for rights to signal what particular patents are worth and how strong they are, just as derivative financial instruments allow markets to evaluate and price other forms of risk. It will help rationalize patent transactions, turning them from secret, one-off negotiations into a real, working market for patents. And by making it clear to courts and the world at large what the normal price is for patent rights, it will make it that much harder for a few unscrupulous patent owners to hold up legitimate innovators, and for established companies to systematically infringe the rights of others.

"Impossible!," patent lawyers are likely to splutter. "No one would license patents if they knew they had to disclose their licenses to the world.” But that objection wrongly assumes that the way patent owners have always done something is the only possible way it can be done. The recent publication of data on home sales prices has helped, not hurt, the real estate market. It should do the same for patents. Patent owners have a product to sell-legal rights to a new technology. If they can find a willing buyer, both sides will have a strong incentive to enter into the transaction even if their deal will be disclosed. And since publication would be required for everyone, having to publish licenses would not disadvantage either side relative to their competitors. Indeed, the law already requires patent owners to disclose their license terms in a few circumstances-where pharmaceutical companies settle with a generic competitor, or where the transaction is large enough that it is material to the bottom line of a publicly-traded company-and those disclosure requirements have not prevented parties from transacting. If Congress were still concerned about the risks of too much disclosure, it could take incremental steps towards greater transparency by requiring parties to patent lawsuits to disclose their settlements, or publicly-traded companies to disclose all their licenses. 
The only people who stand to lose from mandatory disclosure of licenses are those who are taking advantage of the current state of ignorance, whether by holding up defendants or by refusing to pay for technology that everyone else is paying for. But just as we wouldn't prevent the development of a new financial instrument just to protect the interest of an insider trading on their knowledge, we should not use claims of secrecy to prevent the development of a robust market in technology. 